\title{
The Construction of China-Russia-Mongolia Free Trade Area under 'the Belt and Road'-Studies Based on SWOT Analysis
}

\author{
Lulu $\operatorname{Lin}^{1,} \mathrm{a}^{*}$ \\ School of Economics and Management, North China Electric Power University, Beijing, China \\ 15210266195@163.com
}

Keywords: The belt and road; China-Russia-Mongolia free trade area; SWOT analysis

\begin{abstract}
China, Mongolia and Russia economic FTA(Free Trade Area) is an important part of the strategy of 'The Belt and Road'. Promote the construction of China-Russia-Mongolia FTA can not only develop strategic cooperation among the three countries but also act as a significant measure to the construction of the Belt and Road. This paper's purpose is to analyse the current situation, opportunities and threats in the construction of China-Mongolia-Mongolia FTA under 'the Belt and Road' and put forward the corresponding strategies to seize opportunities and avoid threats through the SWOT Analysis.
\end{abstract}

\section{Introduction}

China, Russia and Mongolia are adjacent to each other, and the trade exchanges and cooperation among the three countries have become increasingly frequent in recent years. But theoverall scale and level of economic and trade cooperation among the three countries are relatively low. In the foundation of Economic Corridor through the three countries, explore the establishment of a higher level of FTA, which can effectively promote the 'The Belt and Road 'construction, but also achieve the interconnection of infrastructure and improve the export product structure and energy structure of three countries. On the one hand, 'The Belt and Road' provides new opportunities to deepen economic and trade cooperation, on the other hand, it brings new threats at the same time. Therefore, under 'the Belt and Road' opportunity, China should seize the opportunities, avoid the disadvantages, show friendly demeanour and promote China-Russia-Mongolia economic and trade cooperation into a further upgrade. This paper summarizes the research of professor Fengzhi Huang[1], Xin Li[2] and others, thereby concludes the current advantages and disadvantages of the China-Russia-Mongolia FTA. Through SWOT analysis, this paper lists various internal strengths, weaknesses and external opportunities and threats that are closely related to the FTA establishment, and use the thought of system analysis, match the various factors with each other, we can draw a series of decisional conclusions.

\section{Status}

Strengths(S). Geographical advantage. The geographical location of Mongolia determines that it has only two major economic partners, namely China and Russia. There are 33 open ports in the more than 4300-kilometer border between China and Russia, which can be used to carry out a bilateral trade using a railway, air transport, water transport and highway transportation. [3] With the cooperation between China and Russia's relevant departments, it has completed three railway artery connecting with Siberia railway network in the Russian Far East; Besides, the 18 water transport opening ports in the Heilongjiang waterway have formed an integrated water trading system; what's more, China and Russia have opened more than 10 air routes of transportation.

political advantage. As early as the beginning of the1990s, Russia and China signed the Treaty of Friendship and Cooperation with Mongolia respectively, and the economic and trade cooperation between China, Russia and Mongolia also switched to hard currency settlement. [2]Their cooperation has developed rapidly. They have exchanged in-depth views on priority cooperation and international and regional issues. During the consultations, the issues of mutual interest and 
cooperation prospects were discussed, including mineral development, joint mining, transportation potential, infrastructure construction, tourism, environmental protection and cultural exchanges. In August 2014, President Xi Jinping visited Mongolia and further promoted China-Mongolia relations as a comprehensive strategic partnership. In 2012, Russia's foreign policy began to move eastward. To strengthen the relationship with Mongolia, President Putin paid a working visit to Mongolia in September 2014. Since July 2016, a series of substantive strategic cooperation has been carried out among the three countries, which will accelerate the construction of China Russian Mongolian economic corridor.

the economic structure of the three countries is complementary. Due to resource endowment, the level of scientific and technological development, macroeconomic policies and other factors, China, Russia and Mongolia have different economic structure and dominant industries, which have formed the complementary trade structure. China has a relatively comparative advantage in labour-intensive products, as China's policy has a preference for high-tech products, technology products begin to prominence; While Russia focuses on heavy industry development and belittle light industry. Besides, Russia is a vast territory with a sparse population, which makes Russia at a disadvantage in exporting light industry and other labour-intensive products, but it shows great competitiveness in some sophisticated technology products exportation. Mongolia has a rich natural resource, its vast grassland, developed animal husbandry lead to its strong export competitiveness of mineral, fuel and other resource-intensive products, as well as agricultural and sideline products and by-products. China's exports to Russia are mainly labour-intensive products. While the products imported from Russia are mainly resource-intensive. Mongolia exports resource-intensive products to China to play its comparative advantage, and imports labor-intensive products to meet the needs of domestic production and life, enabling the development of a mutually beneficial relationship between both parties.

Weakness $(\mathbf{W})$. Trade port infrastructure is relatively backward. Economic and trade development depends on the guarantee of transport infrastructure. However, Mongolia and Russia adjacent area traffic infrastructure constructions lagging behind. As Mongolia's economy is relatively backward, resulting in inadequate investment in the domestic transportation infrastructure. Therefore the transportation equipment is ageing and disrepair. Besides, Many problems such as poor customs clearance capacity, poor road traffic capacity and low storage capacity have restricted the transformation and up-gradation of the open ports. The problem of logistics inconvenience caused by railway gauge varies among China, Russia and Mongolia increases the loading and unloading workload and the transportation cost of goods as well as reduces the logistics efficiency.

The border trade is small in scale and simple in structure. In recent years, although the volume of trade among China, Russia and Mongolia is steadily increasing and continues to improve, the overall scale is small, and the structure is single. [4]As for the trade scale, the volume of China-Russian trade has never exceeded $\$ 100$ billion, not to mention the expected level; The trade volume between China and Mongolia is less than $\$ 10$ billion, which is less than $0.2 \%$ of China's total foreign trade. Seeing from the perspective of trade structure, the trade structure of the three countries is unbalanced and relatively unitary. The exports of Russia and Mongolia to China is dominated by resource products, while China's exports to Mongolia are mainly based on low-tech and low-valuelabour-intensive products. Also, Mongolia has strong resource advantages, many products imported from Mongolia are also mine products, such as a large wood raw material type of primary products in Russia. Although there exist some objective factors, in the long term, it will hinder the further cooperation and become the restriction of China, Russia and Mongolia FTA construction.

Opportunities (O). Realize the complementary between the two countries in the import and export commodities and industrial structure. Russia and Mongolia energy products can alleviate the energy shortage situation at the present stage in China, and on our country's energy reserves is of great strategic significance. In the meanwhile, China's mechanical and electrical, light industry products, can also help improve the Russian-Mongolia light industry which is in a backward situation, improve people's living standard at the same time. To achieve sustained development, 
China Russia and Mongolia are adjusting their industrial structure under the guidance of comparative advantages of an international market. China's labour supply exceeds demand, but it can export large quantities of labour-intensive products to Russia or Mongolia. And Russia has strong industrial foundation of science and technology, its working quality is higher, but it's in the shortage of labor force, Russia could adjust current industrial structure to develop the military industry, high-tech industry and intelligence intensive.

The neighboring regions of the three countries have a strong desire for common development through regional cooperation. China's northeastern regions have struggled for years. Russia's resource-rich east and eastern Siberia have long been undeveloped. At the same time, Mongolia has a low population density and a single economic structure, which leads to relatively low economic development. Therefore, China and Russia are facing the urgent need for economic development in the region of the three countries, and the three countries also have a strong will to develop the regional economy.

Threats(T). Mongolia's unstable political environment. Mongolia's misunderstanding of the "China threat theory" poses some cautious attitude towards investment and corporation in our country. Mongolia's constantly changing policy environment will give the China-Russian border trade of the three actors, and foreign investors within the territory of many psychological negative expectations. In the face of unstable and unpredictable policy environment, chamber of commerce, investment trade participants are likely to consider to make a trade, reduce trade and investment, therefore, leading to an investment decision.

Competition increases and the development of national enterprises is threatened. Receiving free trade zone among Mongolia China and Russia in the three markets, there is a difference due to different national advantage industry. At the same time, the development of all industries should be stepped up. What's more, as the trade of the presence of uncertainty, the competition is likely to lead to the lack of confidence in industrial development. If timely adjust strategy doesn't be taken, when the foreign capital enterprises enter the domestic, it is likely to lose market opportunities.

Fake and inferior commodities take the opportunity of free trade to enter the market. After free trade zone among China Mongolia and Russia is completed, the formation of a large market will make a rising demand for commodities, and as the cancellation of tariff and non-tariff barriers, corporation profits will become a big space. Due to the interests of the driver, some trading main body may be in violation of business ethics. In market transactions, even the fake and shoddy products substitution for superior quality will appear in the market. 


\section{SWOT Analysis}

\section{Table 1 SWOT Analysis}

\begin{tabular}{|c|c|c|}
\hline inte & $\begin{array}{l}\text { opportunities } \\
\text { Realize the complementary } \\
\text { between the two countries in } \\
\text { the import and export } \\
\text { commodities and industrial } \\
\text { structure. } \\
\text { The neighboring regions of } \\
\text { the three countries have a } \\
\text { strong desire for common } \\
\text { development through } \\
\text { regional cooperation }\end{array}$ & \begin{tabular}{l}
\multicolumn{1}{c}{ threats } \\
$>\quad \begin{array}{l}\text { Mongolia's unstable political } \\
\text { environment }\end{array}$ \\
$>\quad \begin{array}{l}\text { Competition increases and } \\
\text { the development of national }\end{array}$ \\
enterprises is threatened \\
$>\quad \begin{array}{l}\text { Fake and inferior } \\
\text { commodities take the } \\
\text { opportunity of free trade to } \\
\text { enter the market }\end{array}$
\end{tabular} \\
\hline \begin{tabular}{l}
\multicolumn{1}{c}{ strengths } \\
$>\quad$ Geographical advantage \\
$>\quad$ political advantage \\
the economic structure of \\
the three countries is \\
complementary
\end{tabular} & $\begin{array}{l}\text { Strengthen political and } \\
\text { economic cultural exchanges } \\
\text { Develop e-commerce } \\
\text { platforms across the three } \\
\text { countries } \\
\text { Optimize the structure of } \\
\text { bilateral trade }\end{array}$ & $\begin{array}{l}\text { Improve the border trade } \\
\text { management order } \\
\text { Enhance mutual trust } \\
\text { through cooperation } \\
\text { - Regulate the trading order }\end{array}$ \\
\hline $\begin{array}{l}\text { weaknesses } \\
\quad \text { Trade port infrastructure is } \\
\text { relatively backward } \\
\text { The border trade is small in } \\
\text { scale and simple in structure }\end{array}$ & $\begin{array}{l}\text { Strengthen infrastructure } \\
\text { construction } \\
\text { Adjust bilateral trade of } \\
\text { structure and transform } \\
\text { bilateral } \\
\text { Reduce tariff barriers }\end{array}$ & $\begin{array}{l}\text { Intensify the policy support } \\
\text { of frontier trade in the three } \\
\text { countries } \\
\text { Revitalize national } \\
\text { enterprises }\end{array}$ \\
\hline
\end{tabular}

\section{strategies}

The superiority - opportunity strategy. Strengthen political and economic cultural exchanges. First, Good cooperation is a prerequisite for development, and under the Belt and Road, cooperation is further strengthened. The three governments should establish a free trade agreement, reinforce close communication between governments and promote good-neighborly and friendly relationships. Secondly, it is necessary to promote trade facilitation. Thirdly, measures should be taken to deepen people-to-people and cultural exchanges and deepen medical and health cooperation.

Develop e-commerce platforms across the three countries. E-commerce has developed rapidly in recent years, its development is an significant measure for the development of low cost and for trade benefit from FTA, therefore it is necessary to build the three common e-commerce platform, synchronized browsing and information sharing. And the development of electronic commerce is inseparable from the progress of logistics industry.

Optimize the structure of bilateral trade. As resources endowment in China, Russia, Mongolia is different, economies are highly complementary to each other, cooperation potential and space is very large, mutual benefits and win-win cooperation, economic and cultural exchanges, mechanism innovation and pattern innovation are in urgent need. Firstly, clear the meaning and the key to economic and trade cooperation, speed up the industrial structure adjustment and upgrading. Based on speeding up in the adjustment and upgrading of industrial structure, governments should 
strengthen the direct investment cooperation, complementary experiment industry, promote the healthy operation of the industrial chain division of labour transfer, and increase exchanges and cooperation with nongovernmental enterprises. Secondly, speed up cultivating their multinational corporations, and expand the high value-added products, production and trade, occupy the international division of labour in the industry of high-end, expand new areas of inner industry trade, and optimize trade structure. Moreover, give full play to its comparative advantage, develop a strategic trade industry, expand the scale of trade, to achieve the optimal allocation of economies of scale in among countries, play a technical advantage, Russia and China are more labor-intensive industry investment, at the same time reduce tariff barriers, improve the enthusiasm of cooperation, truly comprehensive trade cooperation and communication.

The advantage - threat strategy. Improve the border trade management order. Cooperation is based on mutual trust, so it is imperative to strengthen the supervision. Concerning the import and export products, overseas factories must be strictly controlled, establish concordant supervision and management mechanism, clear the main responsibility, which will advance the overall supervision. Besides, establish border management accountability. Strict accountability will combine both prevention and accountability. Make the product and quality of service in the management issued standard. At the same time, border trade supervision and management is also an opportunity to improve the quality of products and branding.

Enhance mutual trust through cooperation. China in the process of trade should show the attitude of friendship and cooperation, and seek common development. Make the theory of china threat disappear from both minds. Maintain China's image as a responsible great power, thereby increasing willingness to invest, expand the scale of investment, to further promote trade. Strengthen information sharing, information sharing through mutual learning among organizations, members of the alliance in essence is the flow, transfer, externalization, internalization and standardization, to promote the complementary advantages of resources.

Regulate the trading order. China, Russia, Mongolia are three different countries, so there are differences in the laws and regulations of trade. There are conflicts of interest between the three parties in trade. Take corresponding measures to prevent its negative effects on bilateral trade. At the same time, strengthen the legislative work among the three countries, improve the laws and regulations, and accomplish the task that the all three governance do the security department coordination. What's more, the three parties should work together to tolerate mutual understanding to make great progress in the new period and create a favourable environment for the regular trade.

The disadvantage- opportunity strategy. Strengthen infrastructure construction. Developing the interconnection and transportation infrastructure of China, Russia and Mongolia can reduce the costs of the three countries' trade and effectively improve the efficiency of trade circulation. Infrastructure interconnectivity is not only limited to traditional railway transport, covers international railway, highway, airports, oil and gas pipeline, such that all-round, three-dimensional network of infrastructure. Increase the port infrastructure construction investment, especially the development of railway, highway, water transport, cargo carrying capacity. The Comprehensive transportation network is the construction of three-dimensional, to effectively solve or eliminate the border trade and transportation capacity difference. It will mainly promote the construction of China-Mongolian international railway, especially the parts in Russia and Mongolia. In the process of promoting the construction of infrastructure, pay attention to coordination, take the interests of these countries into account, mobilize the enthusiasm of Mongolia and strive to achieve win-win cooperation between the three countries.

Adjust bilateral trade of structure and transform bilateral. First of all, strengthen the three countries' scientific and technological exchanges and optimize the trade structure. Three countries' technology should increase the intensity of the exchange, and pay attention to guide the development of their own knowledge intensive and capital-intensive industry, optimize the domestic production structure, to avoid the imbalance of industrial structure, the upgrading of the industrial structure, improve value-added products, high-tech products and capital intensive products accounted for in their trade in import the proportion of. Secondly, we should expand 
investment cooperation and achieve all-round economic and trade cooperation. Strengthen exchange and communication between China, Russia and Mongolia among the governments, associations, enterprises. Realize the enterprise oriented to Russia and Mongolia economic and trade cooperation and investment patterns, namely government bypass roads, also association joint communication is required for the development of enterprises and investors.

Reduce tariff barriers. The establishment of FTA among China, Mongolia and Russia also require a better agreement on the reduction of tariff barriers among the three countries. In Mongolia, the trade between China and Russia, if the three countries agree to give more preferential tariff concession to each other, the three countries will continue to expand trade scale and welfare level will gradually improve.

The disadvantage -threat strategy. Intensify the policy support of frontier trade in the three countries. When Mongolia and Russia economic environment is under the condition of weak glue, FTA is an important way to improve the situation, so the governments should seize the bilateral trade opportunities to increase support for efforts to open ports, reduce economic barriers, the stable development of the free trade area of Russia and Mongolia third, promote economic development better.

Revitalize national enterprises. The Belt and Road are bringing more opportunities and challenges, but national enterprises will face increased competition, little accident will make the national industrial countries unrecoverable. Therefore government should give subsidies to national enterprises, enhance their competitiveness, guide them in the fierce competition.

\section{Conclusion}

While the FTA construction has advantages in both geography, politics and economic structure, the trade port infrastructure and border trade still have a lot of room for devwlopments and improvements. With the opportunity of realize the complementary in the commodities and industrial structure, the three countries should optimize the structure of bilateral trade and strengthen infrastructure construction. Besides, in order to aviod threats of unstable political environment and fiercer competition, necessary measures such as improve the border trade management order, intensify the policy support of frontier trade, revitalize national enterprises should be taken.

\section{Reference}

[1]Huang Fengzhi, Strategic analysis on the construction of china-mongolia economic corridor, [A], NSSFC ACHIEVEMENTS, 2016. 13. 007:62-73

[2] Xin Li , Mongolia and Russia economic corridor is an important part of the strategy of 'The Belt and Road' . [J], Siberian Studies, 2016-06-42(3): 5-10

[3]Yijun Xiang, Yangyang Zhao , Analyses on the foundation of China-Russian bilateral free trade area and its trade effect, [J], Commercial Research, 2016-01:140-143

[4]MinghaoWang, Dan Wu, A study on'the Belt and Road' in the background of the China-Russia-Mongolian free trade zone construction, [J], Economic Review, 2016-08:72-76 